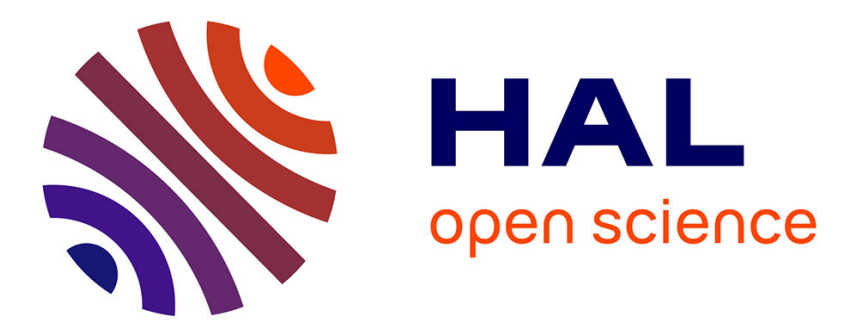

\title{
Stabilization of a supplemental digestive enzyme by post-translational engineering using chemically-activated polyethylene glycol
}

Kevin M. Turner, Gianfranco Pasut, Francesco M. Veronese, Angela Boyce, Gary Walsh

\section{To cite this version:}

Kevin M. Turner, Gianfranco Pasut, Francesco M. Veronese, Angela Boyce, Gary Walsh. Stabilization of a supplemental digestive enzyme by post-translational engineering using chemically-activated polyethylene glycol. Biotechnology Letters, 2010, 33 (3), pp.617-621. 10.1007/s10529-010-0474-7 . hal-00642942

\section{HAL Id: hal-00642942 \\ https://hal.science/hal-00642942}

Submitted on 20 Nov 2011

HAL is a multi-disciplinary open access archive for the deposit and dissemination of scientific research documents, whether they are published or not. The documents may come from teaching and research institutions in France or abroad, or from public or private research centers.
L'archive ouverte pluridisciplinaire HAL, est destinée au dépôt et à la diffusion de documents scientifiques de niveau recherche, publiés ou non, émanant des établissements d'enseignement et de recherche français ou étrangers, des laboratoires publics ou privés. 
Section: Microbial and Enzyme Technology

Stabilization of a supplemental digestive enzyme by post-translational engineering using chemically-activated polyethylene glycol

Kevin M. Turner ${ }^{\text {ab d* }}{ }^{\text {, Gianfranco Pasut }}{ }^{c}$, Francesco M. Veronese ${ }^{c}$, Angela Boyce ${ }^{a b}$ and Gary Walsh $^{a b}$

${ }^{\text {a }}$ Industrial Biochemistry Program, Department of Chemical \& Environmental Sciences, University of Limerick, Limerick, Ireland

${ }^{\mathrm{b}}$ Materials \& Surface Sciences Institute, University of Limerick, Limerick, Ireland

${ }^{c}$ Department of Pharmaceutical Sciences, University of Padova, Via Marzolo 5, Padova, Italy

${ }^{\mathrm{d}}$ Current address: Molecular Glycobiotechnology Group, Biochemistry, National University of Ireland, Galway, Galway, Ireland

*corresponding author

kevinturner2006@gmail.com,

Tel.: +353-87-2401490 


\begin{abstract}
Many enzymes used as digestive aids exhibit, at best, moderate stability when incubated under gastrointestinal conditions. A supplemental $\beta$-galactosidase administered orally to treat lactose intolerance was conjugated to $40 \mathrm{kDa}$, branched polyethylene glycol (PEG). PEGylation increased the enzyme's relative activity at lower pH values (2.5-4.5) and doubled enzyme stability at $\mathrm{pH}$ 2.5. The PEGylated enzyme retained significantly more residual activity after exposure to simulated gastric conditions (52\% versus $31 \%$ ), a consequence of protection from both pepsin and low $\mathrm{pH}$ mediated inactivation. Conjugation also provided significant protection against the proteolytic component of pancreatin. Overall, the PEGylated enzyme retained over twice the levels of residual activity recorded for non-PEGylated enzyme after exposure to complete simulated gastrointestinal conditions. PEGylation also marginally improved the enzyme's kinetic characteristics. When using its physiological substrate (lactose), Km values recorded were slightly decreased (from 83 to $60 \mu \mathrm{M}$ ) and kcat/Km values $\left(\mathrm{M}^{-1} \mathrm{~s}^{-1}\right.$ ) were increased from 100 to 147 . This appears to be the first report of the use of a conjugated PEG to stabilize a digestive enzyme and the first report of the ability of conjugated PEG to stabilize a protein at low $\mathrm{pH}$.
\end{abstract}

Key words:

$\beta$-galactosidase; gastrointestinal; lactase; lactose intolerance; PEGylation 


\section{Introduction}

A wide range of enzymes find application as oral digestive supplements, both for human and animal use (Bedford and Partridge 2001, O’Connell 2006). In order to be effective, digestive supplemental enzymes must be stable and active within the gastrointestinal tract, where they are exposed to various potentially inactivating influences such as low stomach $\mathrm{pH}$ and digestive proteases (Xenos et al. 1998). $\quad \beta$-Galactosidase (lactase) is used to treat lactose maldigestion/ intolerance, a condition affecting up to $75 \%$ of the world's population (Swagerty et al. 2002). Previous studies in the host laboratory indicate that supplemental lactases display poor stability when subjected to in vitro simulated gastrointestinal conditions, which may explain the often variable and sometimes disappointing clinical results obtained with these preparations (O'Connell and Walsh 2006). More recently, we (O'Connell and Walsh 2007, 2008) and others (Wang et al. 2009) have identified several previously uncharacterized $\beta$-galactosidases likely more suited to clinical application than current commercial preparations. However, even these enzymes are somewhat susceptible to digestive proteases and/or low $\mathrm{pH}$ values. Furthermore, their commercialization would be dependent upon further significant technical and regulatory investigation. In vivo stabilization of existing commercialized $\beta$-galactosidases represents an alternative and likely more attractive route to enhancing efficacy. The covalent attachment of polyethylene glycol (PEG) to therapeutic proteins destined for parenteral administration can increase their efficacy, largely by slowing the rate of glomerular filtration and/or decreasing immunogenicity (Pasut and Veronese 2007). PEGylation may also potentially protect therapeutic proteins from serum proteases via steric hindrance (Veronese et al. 1997). We theorize that PEGylation of supplemental $\beta$-galactosidases destined for oral administration might render them more stable by sterically preventing their proteolytic degradation within the digestive tract. This study aims to assess this possibility.

\section{Materials and Methods}

\section{Materials}

Commercial lactase digestive supplement (Trade name 'Lacteeze', derived from Aspergillus oryzae) was obtained from Gelda Scientific, Ontario, Canada. Chemically-activated, 40 kDa branched-PEG (mPEG2-NHS) was purchased from Nektar Therapeutics, Alabama, USA. Additional reagents were purchased from Sigma-Aldrich.

\section{Methods}


Assay of $\beta$-galactosidase was as described by O'Connell and Walsh (2006). Enzyme-PEG conjugation involved coincubation of enzyme $\left(10 \mathrm{mg} / \mathrm{ml}\right.$ in $0.1 \mathrm{M}$ borate buffer, $\mathrm{pH}$ 8.0) with $\mathrm{mPEG} 2-\mathrm{NHS}$ (1:10 molar ratio, $25^{\circ} \mathrm{C}$ with stirring, $4 \mathrm{~h}$ ). Monitoring of conjugate formation and separation of conjugate from both unconjugated enzyme and free PEG was achieved using a Superdex 200 prep-grade, size-exclusion column $(320 \mathrm{ml})$ attached to a HPLC system using $0.1 \mathrm{M}$ sodium phosphate buffer $\mathrm{pH} 6.8$ as mobile phase and $1 \mathrm{ml} / \mathrm{min}$. SDS-PAGE analysis was undertaken using an 8\% (v/v) gel with staining for PEG in accordance with (Kurfurst 1992). Kinetic properties and the effect of temperature and $\mathrm{pH}$ upon enzyme activity and stability was determined as described by O'Connell and Walsh (2007) while the effect of simulated gastrointestinal tract conditions were determined as described by O'Connell and Walsh (2006).

\section{Results and discussion}

Size-exclusion chromatography (Fig. 1) indicated successful PEGylation. The appearance of a single new peak of reduced retention time indicates formation of a monoPEGylated species (the new peak appearing at a longer retention time, 36 min, represents the NHS released from the coupling reaction, (Veronese et al. 2001). Percentage PEGylation was calculated at 55\%, [well within the normal range typically achieved (Veronese 2001)]. MonoPEGylation was confirmed via a TNBS assay (Veronese 2001) and was also supported by SDS-PAGE analysis (Supplementary Fig. 1). In the context of Supplementary Fig. 1, PEG significantly distorts and broadens electrophoretic bands whilst PEG conjugation reduces SDS PAGE electrophoretic mobility, rendering it unsuitable for the molecular mass determination of conjugates (Zheng et al. 2007).

mPEG2-NHS targets accessible surface lysines. Although the primary or higher order structure of the commercial Aspergillus oryzae-derived lactase supplemental enzyme is unavailable, $\beta$-galactosidase sequences amongst Aspergilli are highly conserved (Ryttersgaard et al. 2002). Modelling of the $\beta$-galactosidase from A. oryzae ATCC 42149 (accession number Q2UCZ1) using PyMOL software (www.pymol.org) reveals 16 putative surface lysines. Even when multiple surface lysines are available utilization of high molecular weight, branched PEG generally results in mono-PEGylation, likely due to steric hindrance of further PEG attachment (Veronese 2001). 
Collection of appropriate chromatographic fractions facilitated purification of the PEGylated species (Supplementary Fig. 1), allowing its application-relevant characterization. PEGylation of the $\beta$-galactosidase had no effect upon relative enzyme activity at varying temperatures or upon temperature stability but increased the enzyme's relative activity at lower $\mathrm{pH}$ values ( $\mathrm{pH} 2.5-4.5$; Fig. 2). PEGylation also doubled the enzyme's stability at low $\mathrm{pH}$ with the PEGylated enzyme retaining 22\% $(\mathrm{n}=3)$ residual activity after incubation at $\mathrm{pH} 2.5$ for 30 min, whereas the unPEGylated enzyme retained only $11 \%(n=3)$ after similar treatment. In an application-relevant context, enhanced activity and stability at low $\mathrm{pH}$ is likely beneficial as it infers that the PEGylated enzyme would likely display significantly increased activity and stability at gastric $\mathrm{pH}$ (typically 2.0-5.5).

Independent exposure of both PEGylated and unPEGylated enzyme to simulated gastric and simulated small intestinal tract conditions indicated a clear PEG-stabilizing effect (Table 1). Incubation under simulated gastric conditions illustrates that: (a) enzyme inactivation is mediated by a combination of low $\mathrm{pH}$ inactivation, and proteolytic degradation by pepsin; and (b) that PEGylation provides protection from both influences. While possible protection from proteolysis was anticipated, and indeed formed the initial basis of this study, the stabilizing influence of conjugated PEG against low pH-based enzyme inactivation, to our knowledge, has not been reported previously. Despite consideration and extensively reviewing the pertinent literature no mechanism is obvious by which this is achieved. PEGylation also provides an overall stabilizing effect when incubated under simulated small intestinal conditions, though in this case the primary mode of stabilization is via protection against the proteolytic component of pancreatin (Table 1). After incubation under simulated total gastrointestinal conditions (SGF followed by SIF; Table 1), the PEGylated enzyme retained $25 \%$ of initial activity while the unPEGylated form under the same conditions retains only $12 \%$ of the initial activity. 
PEGylation could potentially negatively affect enzyme kinetics; for example, if conjugation occurred at or near the enzymatic active site. This was a source of concern given that PyMOL-based modelling of the A. oryzae ATCC 42149-derived $\beta$-galactosidase revealed four putative lysines at its active site. However, PEGylation actually marginally enhanced the commercial enzyme's kinetic characteristics when lactose was used as a substrate (Table 2). PEGylation decreased the Km value slightly (from 83to $60 \mu \mathrm{M})$ and marginally increased the Vmax value $\left(8 \times 10^{-3} \mathrm{v} 9\right.$ $\left.\mathrm{x} 10^{-3} \mu \mathrm{M} \mathrm{m_{n }}{ }^{-1}\right)$, increasing the overall kcat value $\left(\mathrm{s}^{-1}\right)$ from $8 \times 10^{-3}$ to $9 \times 10^{-3}$, and increasing the kcat/Km value $\left(\mathrm{M}^{-1}\right.$ $\mathrm{s}^{-1}$ ) from 100 to 147 . This data infers that the PEG is likely conjugated at a point distant from the active site and that it does not exert a detrimental effect upon enzyme conformation. The high molecular weight and branched (i.e. sterically bulky) PEG used was chosen specifically to minimize the possibility of attachment to active site lysines, given that the active site itself likely forms a somewhat less accessible crevice on the enzyme's surface.

In conclusion the results presented indicate that PEGylation improves the application-relevant characteristics of a supplemental commercial $\beta$-galactosidase used in the treatment of lactose intolerance and suggests a wider potential strategy for potential stabilization of supplemental digestive enzymes.

\section{Acknowledgements}

Work funded in part by the Irish Research Council for Science, Engineering and Technology. 


\section{References}

Bedford M, Partridge G (2001) Enzymes in farm animal nutrition. CABI publishing, Oxford, UK

Kurfurst MM (1992) Detection and molecular weight determination of polyethylene glycol-modified hirudin by staining after sodium dodecyl sulfate-polyacrylamide gel electrophoresis. Anal Biochem, 200: 244-248

O’Connell S (2006) Additional therapeutic enzymes. In: McGrath B, Walsh G (eds) Directory of therapeutic enzymes, Tailor and Francis, Florida, pp 261-290

O'Connell S, Walsh G (2006) Physicochemical characteristics of commercial lactases relevant to their application in the alleviation of lactose intolerance. App Biochem Biotechnol 134: 179-191

O'Connell S, Walsh G (2007) Purification and properties of a beta-galactosidase with potential application as a digestive supplement. App Biochem Biotechnol 141: 1-13

O'Connell S, Walsh G (2008) Application relevant studies of fungal beta-galactosidases with potential application in the alleviation of lactose intolerance. App Biochem Biotechnol 149: 129-138

Pasut G, Veronese FM (2007) Polymer-drug conjugation, recent achievements and general strategies. Prog Polym Sci 32:933-961

Ryttersgaard CL, Lo Leggio P, Coutinho M, Henrissat B, Larsen S (2002) Aspergillus aculeatus beta-1,4-galactanase: substrate recognition and relations to other glycoside hydrolases in clan GH-A. Biochem 41: 15135-15143

Swagerty DL, Walling Jr AD, Klein RM (2002) Lactose intolerance. Am Fam Physician

65: 1845-1850

Veronese FM (2001) Peptide and protein PEGylation: a review of problems and solutions. Biomaterials 22: 405-417 
Veronese FM, Caliceti P, Schiavon O (1997) Branched and linear poly(ethylene glycol): Influence of the polymer structure on enzymological, pharmacokinetic, and immunological properties of protein conjugates. J Bioact Compat Pol 12(3): 196-207

Veronese FM, Sacca B, de Laureto PP, Sergi M, Caliceti P, Schiavon O, Orsolini P (2001) New PEGs for peptide and protein modification, suitable for identification of the PEGylation site. Bioconjugate Chem12(1): 62-70

Wang H, Lou H, Bai Y, Wang Y, Yang P, Shi P, Zhang W, Fan Y, Yao B (2009) An acidophilic $\beta$-Galactosidase from Bispora sp. MEY-1 with high lactose hydrolytic activity under simulated gastric conditions. J. Agri. Food Chem. 57, 5535-5541

Xenos K, Kyroundis S, Anagnostidis A, Papastathopoulos P (1998) Treatment of lactose intolerance with exogenous beta-D-galactosidase in pellet form. Eur J Drug Metab 23(2): 350-355

Zheng C, Ma G, Su Z (2007) Native PAGE eliminates the problem of PEG-SDS interaction in SDS-PAGE and provides an alternative to HPLC in characterization of protein PEGylation. Electrophoresis 28(16): 28012807 


\section{Figure captions:}

Fig. 1

Overlay comparison of size exclusion chromatographic elution profiles of PEGylated and unPEGylated $\beta$ galactosidase. Profile 1, unPEGylated enzyme; profile 2 post-PEGylation profile

Fig. 2

pH versus activity profiles of PEGylated and unPEGylated enzyme. Data expressed as a percentage of maximum activity. $100 \%$ activity of the PEGylated enzyme equated to $1014 \mathrm{IU} / \mathrm{ml}$, while for the unpegylated enzyme it equated to $1006 \mathrm{IU} / \mathrm{ml}$ activity. Each value represents mean $\pm \mathrm{SD}(\mathrm{n}=3)$.

Table 1

The effect of in vitro simulated gastrointestinal conditions upon PEGylated and unPEGylated forms of supplemental $\beta$ galactosidase. Each value represents mean $(n=3)$. For each mean value, the associated SDs recorded were in all cases $<7 \%$ of that mean value 


\begin{tabular}{|l|c|c|}
\hline \multirow{2}{*}{ Treatment } & \multicolumn{2}{|c|}{ \% Residual Activity } \\
\cline { 2 - 3 } & UnPEGylated & PEGylated \\
\hline SGF $^{\mathrm{a}}$ & 31 & 52 \\
\hline SGF-NPEP $^{\mathrm{b}}$ & 44 & 56 \\
\hline SIF $^{\mathrm{c}}$ & 7 & 32 \\
\hline SIF-NPAN $^{\mathrm{d}}$ & 48 & 60 \\
\hline SGF+ SIF & 12 & 25 \\
\hline
\end{tabular}

*Values expressed as a percentage of original activity recorded. 100\% activity of the PEGylated enzyme equated to $1014 \mathrm{IU} / \mathrm{mL}$, while for the unpegylated enzyme it equated to $1006 \mathrm{IU} / \mathrm{mL}$ activity

${ }^{\mathrm{a}}$ simulated gastric fluid (SGF), ${ }^{\mathrm{b}}$ simulated gastric fluid without pepsin (SGF-NPEP), ${ }^{\mathrm{c}}$ simulated intestinal fluid (SIF), ${ }^{\mathrm{d}}$ simulated intestinal fluid without pancreatin (SIF-NPAN).

Table 2

The effect of PEGylation upon selected kinetic parameters of the supplemental $\beta$-galactosidase enzyme using physiological substrate (lactose) as well as other commonly employed substrates (ONPG and PNPG) 


\begin{tabular}{|c|c|l|c|c|}
\hline & $\mathrm{K}_{\mathrm{m}}(\mu \mathrm{M})$ & $\begin{array}{l}\text { Vmax } \\
\left(\mu \mathrm{M} \mathrm{min}{ }^{-1}\right)\end{array}$ & $\mathrm{kcat}\left(\mathrm{s}^{-1}\right)$ & $\begin{array}{l}\mathrm{kcat} / \mathrm{K}_{\mathrm{m}} \\
\left(\mathrm{M}^{-1} \mathrm{~s}^{-1}\right)\end{array}$ \\
\hline \multicolumn{5}{|c|}{ Lactose } \\
\hline 'Lacteeze' & 83 & 0.008 & 0.008 & 100 \\
\hline PEG-'Lacteeze' & 60 & 0.009 & 0.009 & 147 \\
\hline \multicolumn{5}{|c|}{ ONPG } \\
\hline 'Lacteeze' & 5 & 0.21 & 50 & $1 \times 10^{7}$ \\
\hline PEG-'Lacteeze' & 5 & 0.20 & 134 & $3 \times 10^{7}$ \\
\hline \multicolumn{7}{|c|}{ PNPG } & 1083 & $2 \times 10^{10}$ \\
\hline 'Lacteeze' & 0.05 & 5 & 2493 & $4 \times 10^{10}$ \\
\hline PEG-'Lacteeze' & 0.06 & 4 &
\end{tabular}

"Kinetic parameters were calculated using the synthetic substrates ONPG/PNPG as well as the natural substrate lactose as described by O'Connell and Walsh (2007). Where appropriate, values are expressed as whole numbers. Each value represents mean $(n=4)$. For each mean value, the associated SDs recorded were in all cases $<1 \%$ of that mean value.

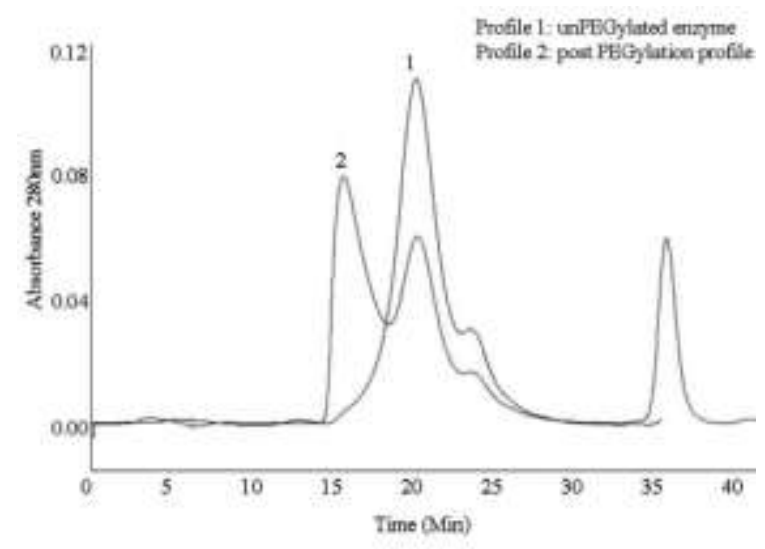

Fig. 1 


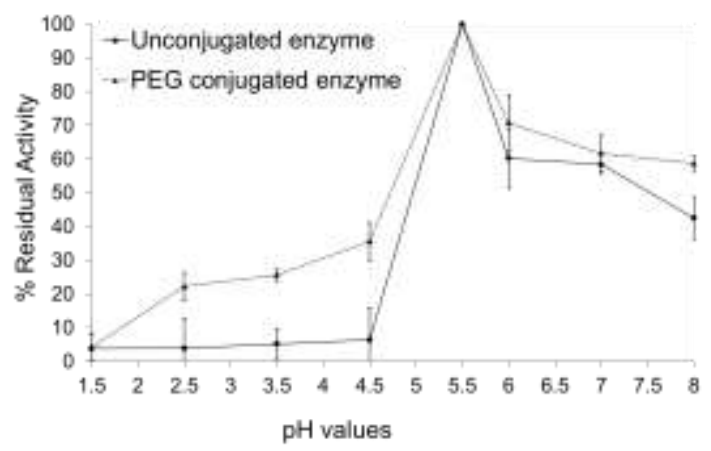

Fig. 2 